\title{
The Quantitative Importance of Openness in Development
}

\author{
Wenbiao Cai, B. Ravikumar and Raymond G. Riezman \\ Department of Economics Working Paper Number: 2013-02
}

\section{THE UNIVERSITY OF WINNIPEG}

\author{
Department of Economics \\ 515 Portage Avenue
}

Winnipeg, R3B 2E9

Canada

This working paper is available for download at: http://ideas.repec.org/s/win/winwop.html 


\title{
The Quantitative Importance of Openness in
}

\author{
Development
}

\author{
Wenbiao Cai* $\quad$ B. Ravikumar ${ }^{\dagger}$ Raymond G. Riezman ${ }^{\ddagger}$
}

August 2013

\begin{abstract}
This paper deals with a classic development question: how can the process of economic development - transition from stagnation in a traditional technology to industrialization and prosperity with a modern technology - be accelerated? Lewis (1954) and Rostow (1956) argue that the pace of industrialization is limited by the rate of capital formation which in turn is limited by the savings rate of workers close to subsistence. We argue that access to capital goods in the world market can be quantitatively important in speeding up the transition. We develop a parsimonious open-economy model where traditional and modern technologies coexist (a dual economy in the sense of Lewis (1954)). We show that a decline in the world price of capital goods in an open economy increases the rate of capital formation and speeds up the pace of industrialization relative to a closed economy that lacks access to cheaper capital goods. In the long run, the investment rate in the open economy is twice as high as in the closed economy and the per capita income is 23 percent higher.
\end{abstract}

JEL codes: O11, F43, O14

Keywords: Openness; Industrialization; Capital formation; Relative price of investment

We thank Manish Pandey and participants at the 2013 Canadian Economics Association meeting for helpful comments. We also thank Judith Ahlers for editorial assistance. The views expressed in this article are those of the authors and do not necessarily reflect the views of the Federal Reserve Bank of St. Louis or the Federal Reserve System.

${ }^{*}$ Department of Economics, University of Winnipeg. we.cai@uwinnipeg.ca

${ }^{\dagger}$ Research Division, Federal Reserve Bank of Saint Louis. b.ravikumar@wustl.edu

${ }_{\ddagger}^{\ddagger}$ Department of Economics, University of Iowa. raymond-riezman@uiowa.edu 


\section{Introduction}

One of the most fundamental questions in development economics is how a poor country with a stagnant economy makes the transition to a modern, growing, and prosperous country. Lewis (1954) and Rostow (1956) start with the observation that the industrialization process is capital intensive and that the absorption of labor into the industrialized sector is limited by the amount of capital. For developing countries the main source of funds for capital formation is domestic savings. Both Lewis and Rostow also observe that these countries have an abundance of unskilled labor that typically has very low productivity. Workers in this situation at best earn subsistence wages and hence there is little or no surplus available for saving. The lack of saving limits the rate of capital formation and, hence, the rate of absorption of labor into the industrialized sector. Thus, the transition from being a poor country to a prosperous one is a gradual process.

How can the process of economic development - transition from stagnation to industrialization - be accelerated? Nurkse (1958), Ranis and Fei (1961), and Rostow (1960) argue that the development process can be accelerated by an increase in agricultural productivity. In their argument, the increase in productivity leads to an increase in surplus that can be used to boost the rate of capital formation, thereby speeding up development.

While the channel of domestic capital formation might be important for closed economies, it is not clear whether the limitations on capital formation imposed by this channel are quantitatively important for open economies. For instance, access to international capital goods markets could provide more funds for capital formation and act as a catalyst for economic development. In this paper, we show that openness in the form of access to capital goods at lower prices increases the rate of capital formation and speeds up the process of economic development.

In our model, there are two technologies - traditional and modern - for producing a single consumption good, as in Hansen and Prescott (2002). During the process of development, both traditional and modern techniques coexist in the economy (i.e., it is a dual economy in 
the sense of Lewis (1954)). We consider the transition from traditional to modern technology as the process of industrialization. The traditional technology is a decreasing returns to scale technology that uses only labor. The modern technology is a constant returns to scale technology that uses both capital and labor. We embed these two technologies into a simple open-economy model of capital accumulation.

An important feature of our model is that there are barriers to capital accumulation. In a closed economy, such barriers distort the price of capital to be higher than that in an open economy. The high price of capital goods in a closed economy leads to slower capital accumulation. In turn, the absorption of labor from traditional to modern technology is slower since the absorption is limited by the amount of capital. Hence, economic development in a closed economy is slow and most of the labor force is employed in the traditional technology. In the open economy, domestic producers gain access to a continually declining international price of capital goods. This international access leads to a more rapid rate of capital accumulation. Faster capital accumulation not only fosters income growth, but also accelerates the absorption of labor into the modern technology.

Table 1 documents the growth of per capita gross domestic product (GDP) and the price of investment relative to consumption for Korea, China, India, and Taiwan. All of these countries experienced major trade liberalization at some point in the latter half of the twentieth century. Table 1 shows that prior to the liberalization, each country exhibits increasing or steady relative price of investment and relatively modest growth rates. This contrasts sharply with post-liberalization periods in which there is faster economic growth along with a steady decline in the relative price of investment. These data suggest a link between the lower price of investment goods and higher economic growth.

This link leads to our main question: How important was access to cheaper capital for accelerating the transition from stagnation to industrialization? We show that it is indeed quantitatively important.

To illustrate the quantitative importance of openness, we use our model and the observed 
Table 1: Annual Growth Rates of Real GDP per Capita and Relative Price of Investment: Before and After Trade Reform

\begin{tabular}{lcc}
\hline \hline & $\begin{array}{c}\text { Pre-reform } \\
\text { (Percent) }\end{array}$ & $\begin{array}{c}\text { Post-reform } \\
\text { (Percent) }\end{array}$ \\
Korea & & 7.4 \\
GDP per capita & 4.0 & -1.6 \\
Relative price & 0.5 & \\
\hline & & 5.4 \\
China & & 0.4 \\
\hline GDP per capita & 1.9 & \\
Relative price & 6.7 & 4.9 \\
\hline & & -0.3 \\
India & & \\
\hline GDP per capita & 2.2 & 7.0 \\
Relative price & 1.2 & -1.7 \\
\hline & & \\
Taiwan & & \\
\hline GDP per capita & 5.5 & \\
Relative price & 1.3 & \\
\hline \hline
\end{tabular}

Source: Penn World Table 7.1 (Heston, Summers, and Aten, 2012). We identify the year of reform as 1969 for Korea, 1978 for China, 1990 for India, and 1960 for Taiwan. Then we compute the average annual percentage change in GDP per capita and the price of investment relative to consumption. We calculate these rates for 20 years before and after the chosen reform year, conditional on availability of data.

postwar development path of South Korea. Korea is a useful laboratory for our model since the decline in the price of investment goods coincided with a set of trade policies introduced in Korea during the 1960s. ${ }^{1}$ These policies explicitly reduced tariffs on capital goods (Westphal (1990) and Rodriguez and Rodrik (2000)). Our model has three exogenous forcing processes - total factor productivity (TFP), population, and the relative price of investment - and three standard parameters - the discount factor, the capital share in the modern technology, and the depreciation rate of capital. Taking the population and relative price of investment in South Korea from the data, we calibrate the TFP to replicate per capita income in South

\footnotetext{
${ }^{1}$ Connolly and Yi (2009) combine a neoclassical growth model with a two-country Ricardian model of trade and vertical specialization and quantify the effect of specific trade policies on Korea's growth relative to G7 countries. They conclude that Korea's trade reforms can account for up to 32 percent of Korea's growth relative to G7 countries. Their framework is not designed to examine how the pace of industrialization is limited by the rate of capital formation in an economy where both modern and traditional technologies coexist.
} 
Korea from 1970 to 2007. The calibrated model is able to reproduce the observed secular decline in the share of the labor force employed in the traditional technology (proxied by the observed share of the rural population). ${ }^{2}$ The model is also able to reproduce the increase in the investment rate.

We then use the calibrated model to measure the quantitative importance of openness for economic development. We conduct a counterfactual exercise in which the price of investment does not decline as observed in the data, but instead remains at the pre-reform (1969) level. We then evaluate the changes to per capita income and the allocation of labor. We find that had the Korean economy remained closed, per capita income would have reached only 80 percent of its observed level in 2007. Moreover, it would have taken 12 more years to reach the fraction of labor employed in the modern technology in 2007. The investment rate increases over time in both open and closed economies, but capital accumulation is more rapid in the open economy. For instance, the investment rate in the open economy in 2007 is twice that in the closed economy. Stated differently, both open and closed economies transition from stagnation to industrialization, but the the transition occurs sooner in the open economy. These results on labor absorption and investment rate are consistent with the arguments in Lewis (1954) and Rostow (1956) that the pace of industrialization is limited by the amount of capital.

In our model, the difference between the paths of GDP per capita in the open and closed economies is due entirely to the difference between the paths of two endogenous variables: capital stock and the fraction of labor in the modern technology. The difference between the paths of GDP per capita can be mechanically accounted for as follows. Starting with the closed economy, we change the share of labor allocated to the modern technology to the share in the open economy and let the path of capital remain the same as that in the closed economy. Such a change in the path of labor leaves the GDP per capita in the closed economy virtually unchanged. This suggests that the difference between the paths of GDP per capita

\footnotetext{
${ }^{2}$ In what follows, we associate the traditional technology with rural areas and modern technology with urban areas and treat industrialization and urbanization as synonymous.
} 
is accounted for by the difference in the paths of capital. To confirm this, we perform the reverse mechanical experiment: Starting with the closed economy, we change the path of capital to the one in the open economy and let the path of labor remain the same as that in the closed economy. This change delivers almost the same path of GDP per capita in the open economy. This implies that capital accumulation is quantitatively more important for the speed of transition from stagnation to industrialization.

The remainder of the paper is organized as follows. Section 2 describes the model. Section 3 discusses the calibration strategy and presents the main quantitative results. Section 4 concludes.

\section{Model}

The economy is populated with $N_{t}$ identical individuals, each endowed with one unit of labor that is supplied inelastically. The economy produces a single good. However, there are two technologies: traditional and modern. The traditional technology requires only labor:

$$
Y_{1 t}=\left(z_{t} H_{1 t}\right)^{1-\alpha},
$$

where $H$ is labor input and $z$ is TFP. The modern technology uses physical capital and labor:

$$
Y_{2 t}=K_{t}^{\alpha}\left(z_{t} H_{2 t}\right)^{1-\alpha},
$$

where $K$ is physical capital. Note that TFP is common to both the traditional and modern technologies. The labor share of output is assumed to the same in both technologies. As will become evident later, this feature is convenient for aggregation and characterizing the dynamics of this economy.

Output can be either consumed or converted into investment goods that add to the capital stock. The conversion of output to investment good is subject to distortions. Specifically, one 
unit of output can be converted into one unit of the consumption good, but only $1 / \pi$ units of the investment good, similar to Parente and Prescott (2002) and Restuccia and Urrutia (2001). Letting $C$ denote consumption and $X$ denote investment, the aggregate resource constraint at time $t$ is given by

$$
\begin{aligned}
& C_{t}+\pi_{t} X_{t}=Y_{1 t}+Y_{2 t}, \\
& H_{1 t}+H_{2 t}=N_{t} .
\end{aligned}
$$

We treat $\pi_{t}$ as a technological parameter that governs the rate of transformation between consumption and investment. This parameter follows a deterministic process described in Section 3. Population grows at the rate $g_{n}$. TFP grows at the rate $g_{z}$. Physical capital depreciates at the rate $\delta$. In the section below, we solve for the efficient allocation.

\subsection{The Social Planner's Problem}

At each date, the social planner decides the allocation of labor between the two technologies and the division of output between consumption and investment, taking the sequence of population, TFP, and the rate of transformation between consumption and investment as given. The social planner's problem is

$$
\begin{aligned}
\max _{\left\{C_{t}, K_{t+1}, H_{1 t}, H_{2 t}\right\}} & \sum_{t=0}^{\infty} \beta^{t} \ln \left(C_{t} / N_{t}\right) \\
\text { s.t. } & C_{t}+\pi_{t} X_{t}=\left(z_{t} H_{1 t}\right)^{1-\alpha}+K_{t}^{\alpha}\left(z_{t} H_{2 t}\right)^{1-\alpha}, \\
& K_{t+1}=(1-\delta) K_{t}+X_{t}, \\
& H_{1 t}+H_{2 t}=N_{t}, \\
& N_{t+1}=\left(1+g_{n}\right) N_{t}, \\
& z_{t+1}=\left(1+g_{z}\right) z_{t}, \\
& K_{0}, N_{0}, z_{0},\left\{\pi_{t}\right\} \text { given. }
\end{aligned}
$$


Equalizing the marginal product of labor across technologies yields the following equation:

$$
K_{t}^{\alpha}\left(z_{t} H_{2 t}\right)^{-\alpha}(1-\alpha)=\left(z_{t} H_{1 t}\right)^{-\alpha}(1-\alpha) .
$$

Rearranging the terms yields the following expression for the fraction of labor in the traditional technology:

$$
h_{1 t}=\frac{H_{1 t}}{N_{t}}=\frac{1}{1+K_{t}} .
$$

Two implications follow from Equation (1). First, the fraction of labor in the traditional technology decreases with the stock of physical capital. As the economy accumulates capital, the economy transitions from a traditional labor-intensive production to a modern capital-intensive one. Second, the fraction of labor in the traditional technology converges to zero as the economy accumulates more and more capital. Thus, the economy converges asymptotically to the neoclassical growth model.

Next we rewrite the planner's problem in efficiency units. Variables in efficiency units are denoted by lowercase letters - that is $c_{t}=C_{t} /\left(z_{t} N_{t}\right), k_{t}=K_{t} /\left(z_{t} N_{t}\right)$. We incorporate the optimal labor allocation into the budget constraint and transform the planner's problem as

$$
\begin{array}{ll}
\max _{\left\{c_{t}, k_{t+1}\right\}} & \sum_{t=0}^{\infty} \beta^{t} \ln \left(z_{t} c_{t}\right) \\
\text { s.t }: & c_{t}+\pi_{t}\left(1+g_{z}\right)\left(1+g_{n}\right) k_{t+1}=\left(k_{t}+\frac{1}{z_{t} N_{t}}\right)^{\alpha}+(1-\delta) \pi_{t} k_{t}, \\
& N_{t+1}=\left(1+g_{n}\right) N_{t}, \\
& z_{t+1}=\left(1+g_{z}\right) z_{t}, \\
& k_{0}, N_{0}, z_{0},\left\{\pi_{t}\right\} \text { given. }
\end{array}
$$

(See the appendix for the derivation of the transformed planner's problem.) The Euler 
equation is given by

$$
\frac{c_{t+1}}{c_{t}}=\frac{\beta}{\left(1+g_{z}\right)\left(1+g_{n}\right)}\left[\frac{\alpha}{\pi_{t}}\left(k_{t+1}+\frac{1}{z_{t+1} N_{t+1}}\right)^{\alpha-1}+(1-\delta) \frac{\pi_{t+1}}{\pi_{t}}\right]
$$

The Euler equation is standard, with the left-hand side representing the ratio of marginal utilities and the right-hand side representing the gross return to capital. The return to capital is less standard; we discuss its implications below. First, the return to capital is finite at $k_{t+1}=0$. The implication is that if the economy starts with no capital, then the modern technology does not operate and capital investment might become profitable only

after an extended period. Second, the economy will eventually transition from stagnation to industrialization provided TFP and/or the population grow because even when the capital stock is zero, the return to capital converges to infinity as $z_{t+1} N_{t+1}$ converges to infinity. Lastly, the timing of such a transition depends on the size of the population $\left(N_{t}\right)$, the level of technology $\left(z_{t}\right)$, and the barriers to investment $\left(\pi_{t}\right)$. In particular, the transition to modern growth occurs sooner with a larger population, a higher level of technology, and fewer barriers to investment. In the next section, we evaluate the importance of openness for transition to modern growth.

\section{Quantitative Implications}

We calibrate the model using Korean data assuming that 1970 marks the beginning of Korea's open economy. We measure the rate of transformation between consumption goods and investment goods by the relative price of investment. We feed the observed sequences of the relative price of investment and population as exogenous inputs to our model. We then choose the labor-augmenting technological progress and other model parameters to reproduce the 
long-run growth of output per capita and other key macroeconomic variables in the data. ${ }^{3}$ Finally, we consider a counterfactual in which (i) the economy remains closed and (ii) the relative price of investment remains at the pre-liberalization (1969) level, and evaluate the changes to GDP per capita and allocation of labor across the two technologies.

\subsection{Calibration}

The model period is one year and the first period corresponds to 1970. Our model is parsimonious: We have only three parameters, $\beta, \delta$, and $\alpha$, and three forcing processes, $\left\{\pi_{t}\right\}$, $\left\{N_{t}\right\}$, and $\left\{z_{t}\right\}$, with the latter two processes assumed to have constant growth rates. We set the discount factor $\beta=0.97$. Capital depreciates annually at the rate $\delta=0.06$. We assign the capital share in the modern technology $\alpha=1 / 3$. These values are standard in the literature.

The relative price of investment sequence $\left\{\pi_{t}\right\}$ is pinned down as follows. We compute the ratio of the purchasing power parity (PPP) price of investment to the PPP price of consumption, both available from Penn World Table 7.1. From 1970 to 2007, we fit the data with a second-degree polynomial and assign the fitted value to $\pi_{t}$. After 2007 , we assume that $\pi_{t}$ remains constant at the 2007 fitted value. Figure 1 plots the relative price in the data along with the fitted polynomial.

The population data are from the World Bank's World Development Indicators. We set $g_{n}$ to the observed average annual population growth for Korea from 1970 to 2007.

Next, we choose initial conditions for the model. We normalize the initial labor force $N_{0}=1$, leaving the initial capital per efficiency worker $\left(k_{0}\right)$ and the initial level of TFP $\left(z_{0}\right)$ to be determined. We use two pieces of data for Korea in 1970 to help pin down these two values. First, the share of the rural population is 60 percent. Second, we compute the

\footnotetext{
${ }^{3}$ Betts, Giri, and Verma (2011), Sposi (2012), Teignier (2012), and Uy, Yi, and Zhang (2013) are recent examples of papers that study structural change in Korea. However, these papers do not consider the effect of changes in the relative price of investment. Furthermore, our focus is on the pace of industrialization in a dual economy à la Lewis (1954), where the absorption of labor in the modern technology is affected by the rate of capital formation.
} 
capital stock in 1970 using investment series from Penn World Table 7.1 with the perpetual inventory method and determine that the capital-output ratio in 1970 is 1.0. We then use two equations from the model that determine the fraction of labor allocated to the traditional technology and the capital-output ratio to match the two observed moments:

$$
\left[\begin{array}{c}
\left(1+k_{0} z_{0}\right)^{-1} \\
k_{0} \cdot\left(k_{0}+1 / z_{0}\right)^{-\alpha}
\end{array}\right]=\left[\begin{array}{c}
0.6 \\
1.0
\end{array}\right]
$$

The solution to the above system is $\left[k_{0}, z_{0}\right]=[1.58,0.42]$.

Finally, having chosen the parameter values and exogenous sequences, we choose the TFP growth to match average annual per capita GDP growth in Korea from 1970 to 2007. Figure 2 plots the per capita GDP sequence from the model and the data.

Before we move to the counterfactual exercise, we discuss two implications of the model that we do not target in the calibration. First, even though we calibrate only to the initial share of rural population, the model is able to reproduce the observed decline in this share, although the decline in the model is more rapid. In the data, the share of the rural population declines to 42 percent in 1980 and 20 percent in 2005. In the model, the share declines to 42 percent in 1980 and 5 percent in 2005 as illustrated in Figure 3. Second, in the model, investment as a share of GDP starts low and gradually increases to a constant level. This feature of the investment rate is roughly consistent with the growth experience of Korea. Over the 1970-2005 period, the investment rate increases from 20 percent to 35 percent in the data. In the model, the investment rate starts at a lower level of 5 percent and increases to 25 percent by 2005, an increase of 20 percentage points relative to the observed increase of 15 percentage points (Figure 4). Chang and Hornstein (2012), who focus on explaining the dynamics of investment rates in Korea, also deliver the increasing pattern of investment rate in a multisector model with declining capital goods prices. However, labor allocation across sectors is exogenous in their model, so they do not address the issue of labor absorption during the process of industrialization discussed in Lewis (1954) and Rostow (1956). 


\subsection{Counterfactuals}

We now consider a counterfactual experiment in which Korea's economy remains closed after 1969. Specifically, the closed economy is assumed to have a different sequence of the relative price of investment but is otherwise identical to the benchmark open economy. That is, both open and closed economies are subject to the same exogenous sequence of population and TFP and have identical initial conditions.

To determine the counterfactual sequence of the relative price for the closed economy, note that the price of investment relative to consumption in the data is fairly constant prior to trade liberalization. The average annual change of the relative price in the data from 1953 to 1969 is close to zero. Consistent with this fact, we assume that in the closed economy the relative price of investment is constant at the pre-liberalization (1969) level.

Per capita income To compare the paths of per capita GDP, we compute the ratio of GDP per capita in the closed economy relative to that in the open economy. Table 2 lists this ratio by decade. Starting from the same level, the closed economy loses ground to the open economy over time, and more so further into the future. The last row of the table suggests that if Korea's economy had remained closed, per capita GDP would have been 20 percent lower than in the open economy by 2007.

Table 2: GDP per Capita: 1970-2007

\begin{tabular}{cc}
\hline \hline Year & GDP per capita (closed/open) \\
\hline 1970 & 1.00 \\
1980 & 0.98 \\
1990 & 0.90 \\
2000 & 0.83 \\
2007 & 0.80 \\
\hline \hline
\end{tabular}

Next, we consider the long-run implication for per capita income. For concreteness, we assume that a generation equals 35 years. We calculate the per capita income of each generation relative to the 1970 generation. Table 3 shows the generational per capita income 
in the closed economy relative to that in the open economy. The last row suggests that in the long run, per capita income is 23 percent lower in the closed economy.

Table 3: Long-Run GDP per Capita

\begin{tabular}{lc}
\hline \hline Generation & GDP per capita (closed/open) \\
\hline $1^{\text {st }}$ & 1.00 \\
$2^{\text {nd }}$ & 0.80 \\
$3^{\text {rd }}$ & 0.77 \\
$4^{\text {th }}$ & 0.77 \\
$\infty$ & 0.77 \\
\hline \hline
\end{tabular}

To see this analytically, recall that our model converges asymptotically to the neoclassical growth model as population and technology grow - that is, as $1 /\left(z_{t} N_{t}\right)$ converges to 0 (see the appendix). In our calibration, $\pi_{t}$ converges to a long-run value $\pi^{*}$, so capital and consumption per efficiency worker converge asymptotically to a constant level. In steady state, Euler equation (2) becomes

$$
1=\frac{\beta}{\left(1+g_{z}\right)\left(1+g_{n}\right)}\left[\frac{\alpha}{\pi^{*}} k^{* \alpha-1}+(1-\delta)\right],
$$

where $k^{*}$ is the steady-state capital stock per efficiency worker. Rearranging the terms yields the following expression for $k^{*}$ :

$$
k^{*}=\left(\frac{\pi^{*}}{\alpha}\left[\frac{\left(1+g_{z}\right)\left(1+g_{n}\right)}{\beta}-(1-\delta)\right]\right)^{\frac{1}{\alpha-1}} .
$$

The sequence of the relative price converges to $\pi_{\mathrm{open}}^{*}=0.72$ in the open economy; in the closed economy, it is assumed to be constant forever at $\pi_{\text {closed }}^{*}=1.32$. Since the open and closed economies are otherwise identical, we can express the ratio of output per efficiency worker in the closed economy to that in the open economy as

$$
\frac{y_{\text {closed }}^{*}}{y_{\text {open }}^{*}}=\left(\frac{k_{\text {closed }}^{*}}{k_{\text {open }}^{*}}\right)^{\alpha}=\left(\frac{\pi_{\text {closed }}^{*}}{\pi_{\text {open }}^{*}}\right)^{\frac{\alpha}{\alpha-1}}=\left(\frac{1.32}{0.72}\right)^{-\frac{1}{2}}=0.77 .
$$


Thus, in the long run, the closed economy's per capita income is 23 percent lower relative to the open economy's per capita income.

Investment rate Investment rate $\left(\frac{X_{t}}{Y_{1 t}+Y_{2 t}}\right)$ differs substantially between the closed economy and the open economy. Access to capital at lower prices in the open economy stimulates faster capital accumulation and a higher investment rate. As Table 4 shows, by 2007 the investment rate in the open economy is almost twice that in the closed economy.

Table 4: Investment as a Share of GDP

\begin{tabular}{ccc}
\hline \hline Year & Open economy & Closed economy \\
\hline 1970 & 0.05 & 0.05 \\
1980 & 0.15 & 0.11 \\
1990 & 0.23 & 0.14 \\
2000 & 0.28 & 0.15 \\
2007 & 0.29 & 0.15 \\
\hline \hline
\end{tabular}

There is a simple connection between the open and closed economies in our model via the investment rate. Suppose we fix the investment rate in our open economy to be the same as the investment rate in the closed economy. That is, we feed the closed-economy sequence of $\frac{X_{t}}{Y_{1 t}+Y_{2 t}}$ into the open economy along with the sequence of population and TFP. Starting from the same initial conditions, the optimal sequence of labor allocation in this case would be identical to the sequence of labor allocation in the closed economy. To see this, note that the optimal labor allocation in period 0 is given by equation (1) and is the same in both open and closed economies. Thus, the total output in period 0 would be the same in both economies. Given the exogenous closed-economy investment rate $\frac{X_{0}}{Y_{10}+Y_{20}}$, the investment $X_{0}$ and the capital stock in period 1 would then be the same as those in the closed economy and, hence, the labor allocation and total output in period 1 would be the same as those in the closed economy. Applying the same logic to subsequent periods, it is easy to see that the GDP per capita sequence in this case would be exactly the same as that in the closed economy. Thus, if we force the investment rate in the open economy to be the same as that in the closed economy, then the resulting (endogenous) labor allocation and GDP per capita 
sequence are the same as those in the closed economy. (In this calculation, note that the relative price of investment and the Euler equation (2) are irrelevant since we are directly feeding in the investment rate.)

Urbanization In our model economy, the share of labor employed in traditional technology declines with capital accumulation. In both the open and closed economies, there is a secular reallocation of labor from the traditional to the modern technology. However, there is a sharp difference in the speed of such reallocation. Since capital accumulation is faster in the open economy, labor moves more rapidly from the traditional to the modern technology. Table 5 shows the share of labor employed in traditional technology for the two economies. Starting from the same level, the share of labor in the traditional technology declines faster in the open economy. For example, by 2007 only 6 percent of labor is employed in the traditional technology in the open economy. The closed economy manages to reach the same level only 12 years later.

Table 5: Share of Labor Employed in Traditional Technology

\begin{tabular}{ccc}
\hline \hline Year & Open economy & Closed economy \\
\hline 1970 & 0.60 & 0.60 \\
1980 & 0.46 & 0.49 \\
1990 & 0.22 & 0.30 \\
2000 & 0.10 & 0.17 \\
2007 & 0.06 & 0.11 \\
& & 0.06 \\
2019 & & \\
\hline \hline
\end{tabular}

\subsection{Accounting for Differences in GDP}

In our model, the difference between the paths of GDP per capita in the open and closed economies is due entirely to the difference between the paths of two endogenous variables: the capital stock and the share of labor employed in the modern technology. Ultimately, the difference between the paths of GDP per capita is accounted for almost entirely by the 
difference in the paths of capital. The difference between the paths of GDP per capita can be mechanically accounted for as follows. We can express GDP per capita in the closed economy as a function of capital stock per capita $\left(\frac{K}{N}\right)$ and labor shares $\left(\frac{H_{1}}{N}, \frac{H_{2}}{N}\right)$ :

$$
\frac{Y_{t}^{\text {closed }}}{N_{t}}=F\left(\frac{K_{t}^{\text {closed }}}{N_{t}}, \frac{H_{1 t}^{\text {closed }}}{N_{t}}, \frac{H_{2 t}^{\text {closed }}}{N_{t}}\right) .
$$

We now perform two calculations. First we change the labor shares to those in the open economy, keeping the capital sequence unchanged. That is, the labor absorption in the closed economy is exogenously forced to be the same as that in the open economy. We then calculate a new sequence of GDP per capita, $\frac{Y_{t}^{1}}{N_{t}}$, as follows:

$$
\frac{Y_{t}^{1}}{N_{t}}=F\left(\frac{K_{t}^{\text {closed }}}{N_{t}}, \frac{H_{1 t}^{\text {open }}}{N_{t}}, \frac{H_{2 t}^{\text {open }}}{N_{t}}\right)
$$

Figure 5 plots $\frac{Y_{t}^{1}}{N_{t}}$ along with the GDP per capita sequence from the closed and open economies. It is clear from the figure that the counterfactual path of GDP per capita is almost identical to that for the closed economy. In fact, per capita GDP is slightly less than that in the closed economy since the allocation of labor is not optimal given the capital stock sequence. This suggests that the difference in paths of GDP per capita between open and closed economies in our model comes from the difference in the capital stock, instead of the difference in labor allocation. To confirm this, we perform the second calculation. We change the capital sequence to that in the open economy, keeping the labor allocation the same as in the closed economy. That is, we calculate another GDP per capita sequence, $\frac{Y_{t}^{2}}{N_{t}}$, as follows:

$$
\frac{Y_{t}^{2}}{N_{t}}=F\left(\frac{K_{t}^{\text {open }}}{N_{t}}, \frac{H_{1 t}^{\text {closed }}}{N_{t}}, \frac{H_{2 t}^{\text {closed }}}{N_{t}}\right) .
$$

Figure 6 plots $\frac{Y_{t}^{2}}{N_{t}}$ along with GDP per capita sequences from the closed and open economies. It is clear from the figure that changing the path of capital to the one in the open economy delivers almost the same path as for GDP per capita in the open economy. 
We conclude that the difference in GDP per capita between the closed and open economies is driven entirely by faster capital accumulation in the open economy, which in turn is driven by international access to cheaper capital goods. With less capital in the closed economy, labor absorption per se does not yield more output since labor in the modern technology is not as productive as in the open economy. Both mechanical accounts reinforce the argument in Lewis (1954) and Rostow (1956) that the pace of industrialization and the speed of transition to modern growth are limited by the amount of capital.

\subsection{One-Sector Model}

We have shown that access to capital at a lower price from the world market could significantly speed up capital formation, absorption of labor into the industrialized sector, and the transition to modern growth. A natural question at this stage might be whether a onesector, open-economy model could deliver the rapid transition. By construction, the onesector model cannot be used to discuss the labor absorption into the industrialized sector emphasized by Lewis (1954) and Rostow (1956). Nevertheless, the implications of declining capital goods prices for other aspects of economic development can be investigated.

Suppose we consider an alternative version of the model in which the traditional technology does not operate. That is, our benchmark model collapses into the neoclassical growth model. To calibrate this model, let the sequences of the relative price of capital goods and population remain the same as in the benchmark model. Choose the initial capital stock to match the capital-output ratio in 1969. As before, normalize the initial TFP to be 1 , and choose the growth rate of TFP to match the average growth rate of per capita GDP between 1970 and 2007. The one-sector model predicts that the investment rate starts high and then declines for several periods before it increases again. This U-shaped pattern of investment rate is not consistent with the data. The fact that the standard neoclassical growth model is at odds with the Korean data on investment rates was noted earlier by Chang and Hornstein (2012). Our benchmark model, on the other hand, implies an increasing investment rate, a 
pattern qualitatively consistent with the data. Furthermore, the pattern is consistent with the observation in Lewis (1954) and Rostow (1956) that capital formation is slow at early stages of development.

\section{Conclusion}

Capital formation has long been regarded as critical to the pace of industrialization and the absorption of labor into the modern, industrialized sector. We argue that access to capital goods in the world market at lower prices can speed up the process of industrialization. We provide evidence from several countries that experienced major trade liberalizations in the latter half of the twentieth century. In these countries, episodes of rapid growth coincide with a continually declining relative price of investment after reform.

We construct a parsimonious open-economy growth model where both traditional and modern technologies coexist similar to Lewis (1954). To test our theory, we first calibrate the model to the postwar growth experience of Korea, taking the relative price of investment as given from the data. We then perform a counterfactual experiment in which the relative price of investment does not decline as observed in the data. We find that (i) the openeconomy investment rate is twice as high as the closed-economy investment rate in the long run and (ii) the GDP per capita is 23 percent higher in the open economy. It also takes 12 more years for the closed economy to reduce the share of rural population to the same level as the open economy. We also show through mechanical accounting exercises that the rate of capital formation is the key driver of the differences between the paths of open and closed economies. 


\section{References}

Betts, C. M., R. Giri, and R. Verma (2011). Trade, Reform, and Structural Transformation in South Korea. Working Paper, University of Southern California.

Chang, Y. and A. Hornstein (2012). Transition Dynamics in the Neoclassical Growth Model: The Case of South Korea. Federal Reserve Bank of Richmond Working Paper No. 11-04R.

Connolly, M. and K.-M. Yi (2009). How Much of South Korea's Growth Miracle Can Be Explained by Trade Policy? Federal Reserve Bank of Philadelphia Working Papers 09-19.

Hansen, G. D. and E. C. Prescott (2002). Malthus to Solow. American Economic Review 92(4), 1205-17.

Heston, A., R. Summers, and B. Aten (July 2012). Penn World Table Version 7.1. Center for International Comparisons of Production, Income and Prices at the University of Pennsylvania.

Lewis, A. W. (1954). Economic Development with Unlimited Supplies of Labor. Manchester School of Economic and Social Studies 22(2), 139-91.

Nurkse, R. (1958). Problems of Capital Formation in Underdeveloped Countries. New York: Oxford University Press.

Parente, S. L. and E. C. Prescott (2002). Barriers to Riches. Cambridge, MA: MIT Press.

Ranis, G. and J. C. H. Fei (1961). A Theory of Economic Development. American Economic Review 51(4), 533-65.

Restuccia, D. and C. Urrutia (2001). Relative Prices and Investment Rates. Journal of Monetary Economics 47(1), 93-121.

Rodriguez, F. and D. Rodrik (2000). Trade Policy and Economic Growth: A Skeptic's Guide to the Cross-National Evidence. In B. S. Bernanke and K. Rogoff (Eds.), NBER Macroeconomics Annual, Volume 15, pp. 261-338. Cambridge: MIT Press.

Rostow, W. W. (1956). The Take-Off into Self-Sustained Growth. Economic Journal 66(261), $25-48$.

Rostow, W. W. (1960). The Stages of Economic Growth: A Non-Communist Manifesto. Cambridge, UK: Cambridge University Press.

Sposi, M. (2012). Evolving Comparative Advantage, Structural Change, and the Composition of Trade. Working Paper, Federal Reserve Bank of Dallas.

Teignier, M. (2012). The Role of Trade in Structural Transformation. Working Paper, Universitat de Barcelona.

Uy, T., K.-M. Yi, and J. Zhang (2013). Structural Change in an Open Economy. Journal of Monetary Economics 60(6), 667-82. 
Westphal, L. E. (1990). Industrial Policy in an Export Propelled Economy: Lessons From South Korea's Experience. The Journal of Economic Perspectives 4 (3), 41-59. 


\section{Appendix}

\section{Transformed social planner's problem}

First note that from the optimal condition (1), we have $\frac{H_{2 t}}{N_{t}}=\frac{K_{t}}{1+K_{t}}$. The aggregate resource constraint is

$$
C_{t}+\pi_{t} K_{t+1}=\left(z_{t} H_{1 t}\right)^{1-\alpha}+K_{t}^{\alpha}\left(z_{t} H_{2 t}\right)^{1-\alpha}+(1-\delta) \pi_{t} K_{t} .
$$

Dividing both sides by $z_{t} N_{t}$ yields

$$
\begin{aligned}
c_{t}+\left(1+g_{z}\right)\left(1+g_{n}\right) \pi_{t} k_{t+1} & =\left(\frac{1}{1+K_{t}}\right)^{1-\alpha}\left(z_{t} N_{t}\right)^{-\alpha}+k_{t}^{\alpha}\left(\frac{K_{t}}{1+K_{t}}\right)^{1-\alpha}+(1-\delta) \pi_{t} k_{t} \\
& =\left(\frac{1}{1+K_{t}}\right)^{1-\alpha}\left(z_{t} N_{t}\right)^{-\alpha}+\left(\frac{K_{t}}{z_{t} N_{t}}\right)^{\alpha}\left(\frac{K_{t}}{1+K_{t}}\right)^{1-\alpha}+(1-\delta) \pi_{t} k_{t} \\
& =\left(\frac{1}{1+K_{t}}\right)^{1-\alpha}\left(z_{t} N_{t}\right)^{-\alpha}+\frac{K_{t}}{\left(1+K_{t}\right)^{1-\alpha}}\left(z_{t} N_{t}\right)^{-\alpha}+(1-\delta) \pi_{t} k_{t} \\
& =\left[\left(\frac{1}{1+K_{t}}\right)^{1-\alpha}+\frac{K_{t}}{\left(1+K_{t}\right)^{1-\alpha}}\right]\left(z_{t} N_{t}\right)^{-\alpha}+(1-\delta) \pi_{t} k_{t} \\
& =\frac{1+K_{t}}{\left(1+K_{t}\right)^{1-\alpha}}\left(z_{t} N_{t}\right)^{-\alpha}+(1-\delta) \pi_{t} k_{t} \\
& =\left(\frac{1+K_{t}}{z_{t} N_{t}}\right)^{\alpha}+(1-\delta) \pi_{t} k_{t} \\
& =\left(k_{t}+\frac{1}{z_{t} N_{t}}\right)^{\alpha}+(1-\delta) \pi_{t} k_{t} .
\end{aligned}
$$


Figure 1: Relative Price of Investment in Korea (1970-2007)

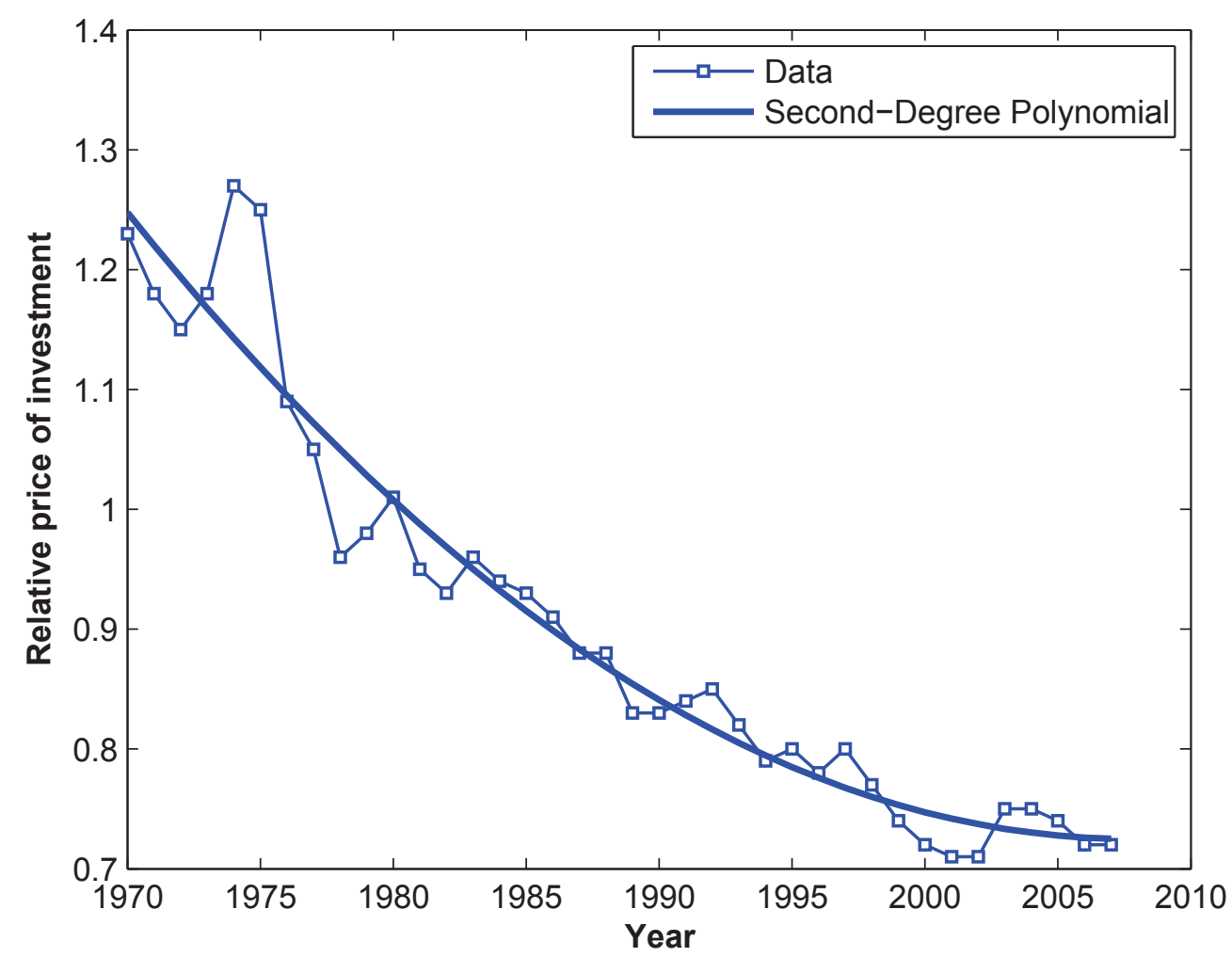

Source: Penn World Table 7.1. Relative price of investment is the ratio of PPP price of investment to PPP price of consumption, both measured in 2005 international dollars. 
Figure 2: GDP per Capita: Model and Data

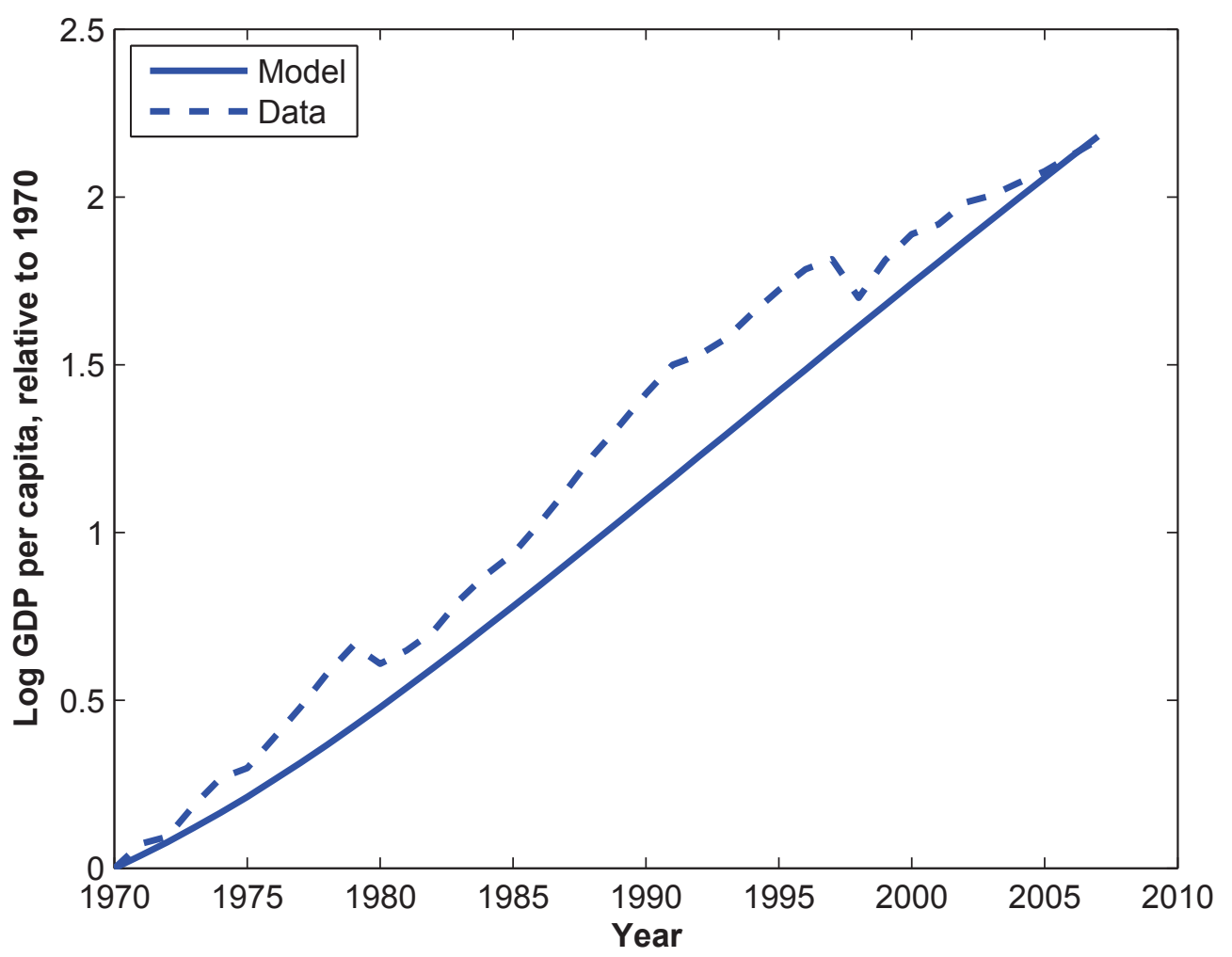

Source: Penn World Table 7.1. 
Figure 3: Share of Rural Population: Model and Data

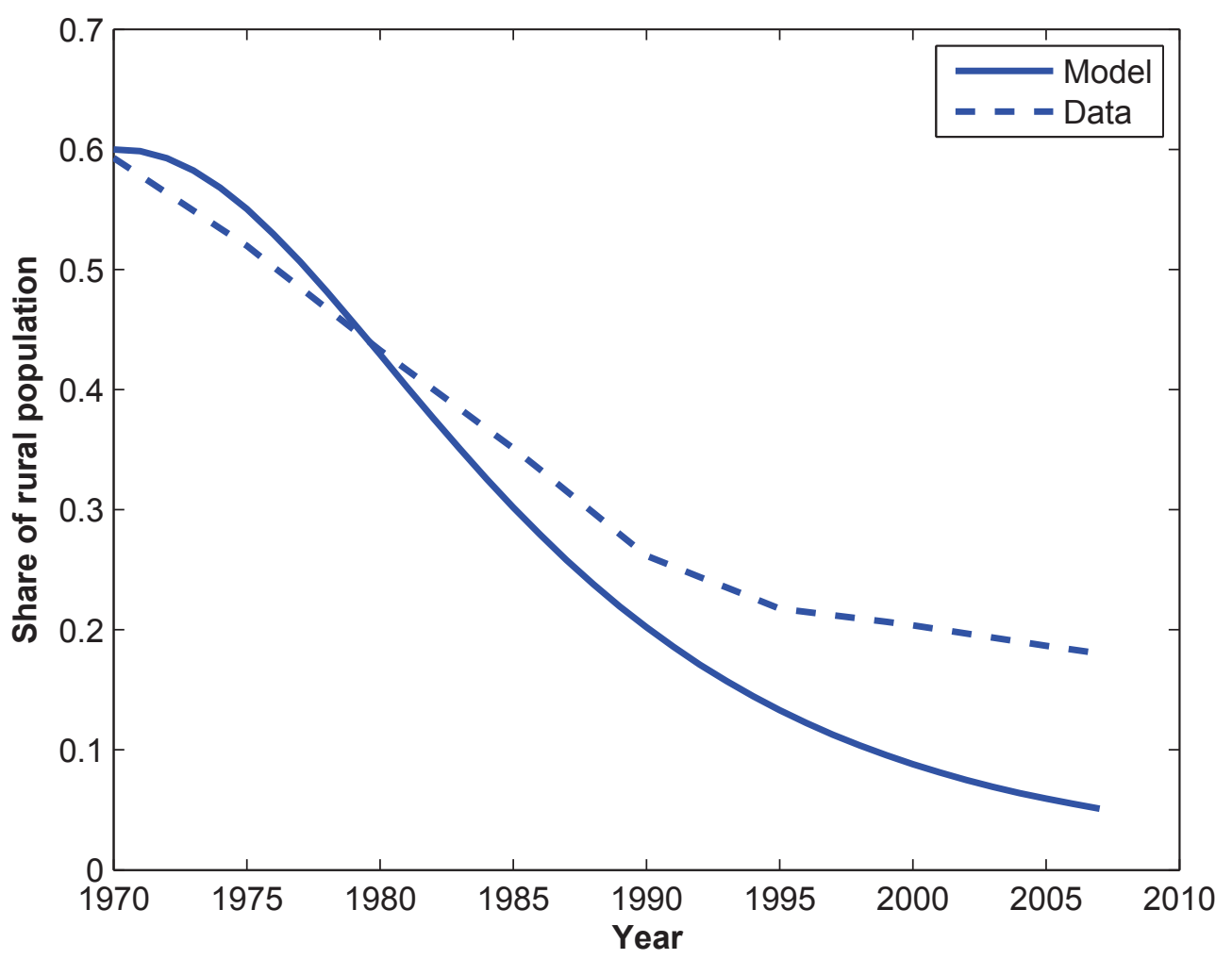

Source: World Development Indicators. 
Figure 4: Investment Share of GDP: Model and Data

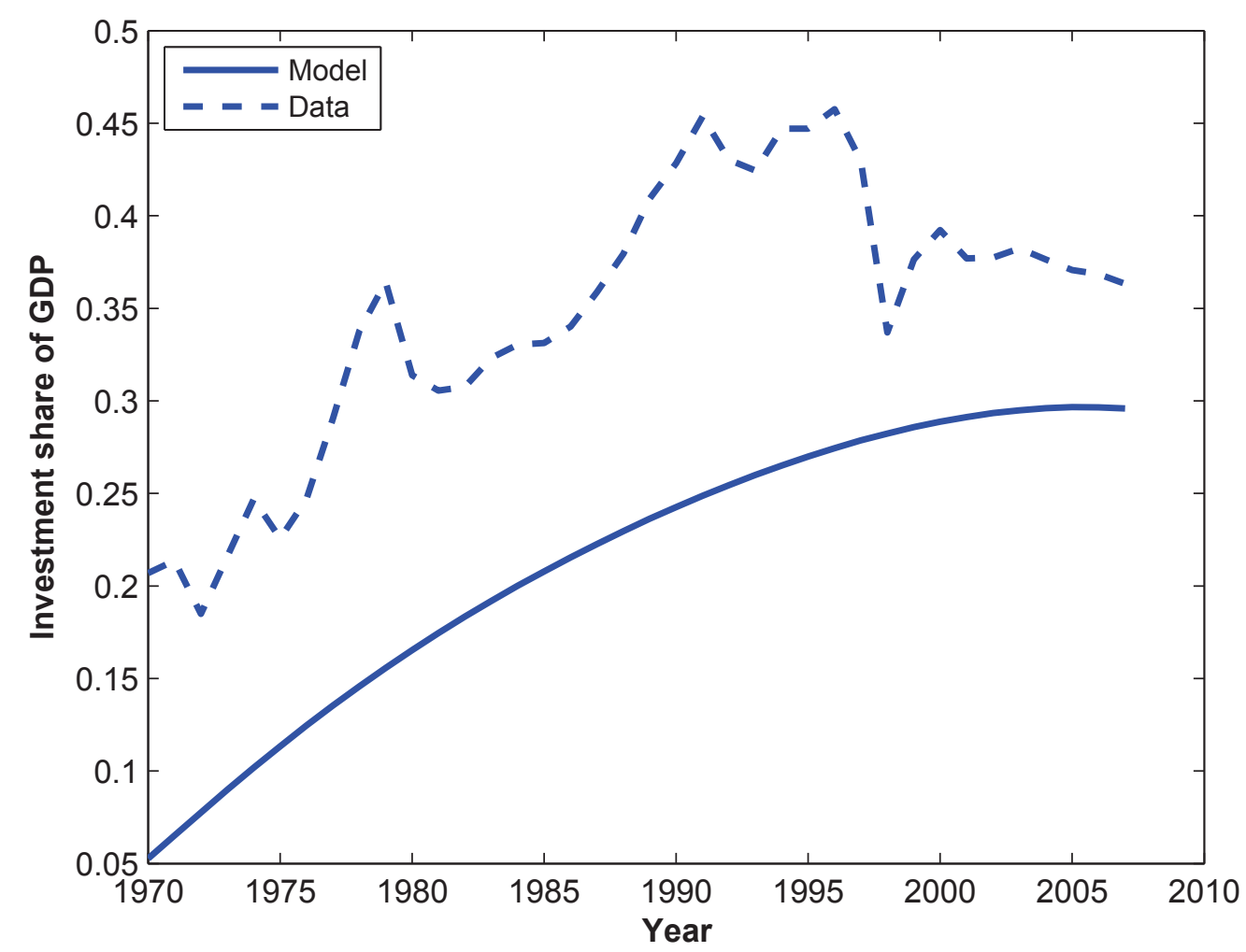

Note: Data refer to the investment share in constant 2005 price (series ki) from Penn World Table 7.1. We use 2005 PPP price of investment and GDP to compute the implied investment share from the model. 
Figure 5: GDP per Capita: Closed-Economy Capital and Open-Economy Labor

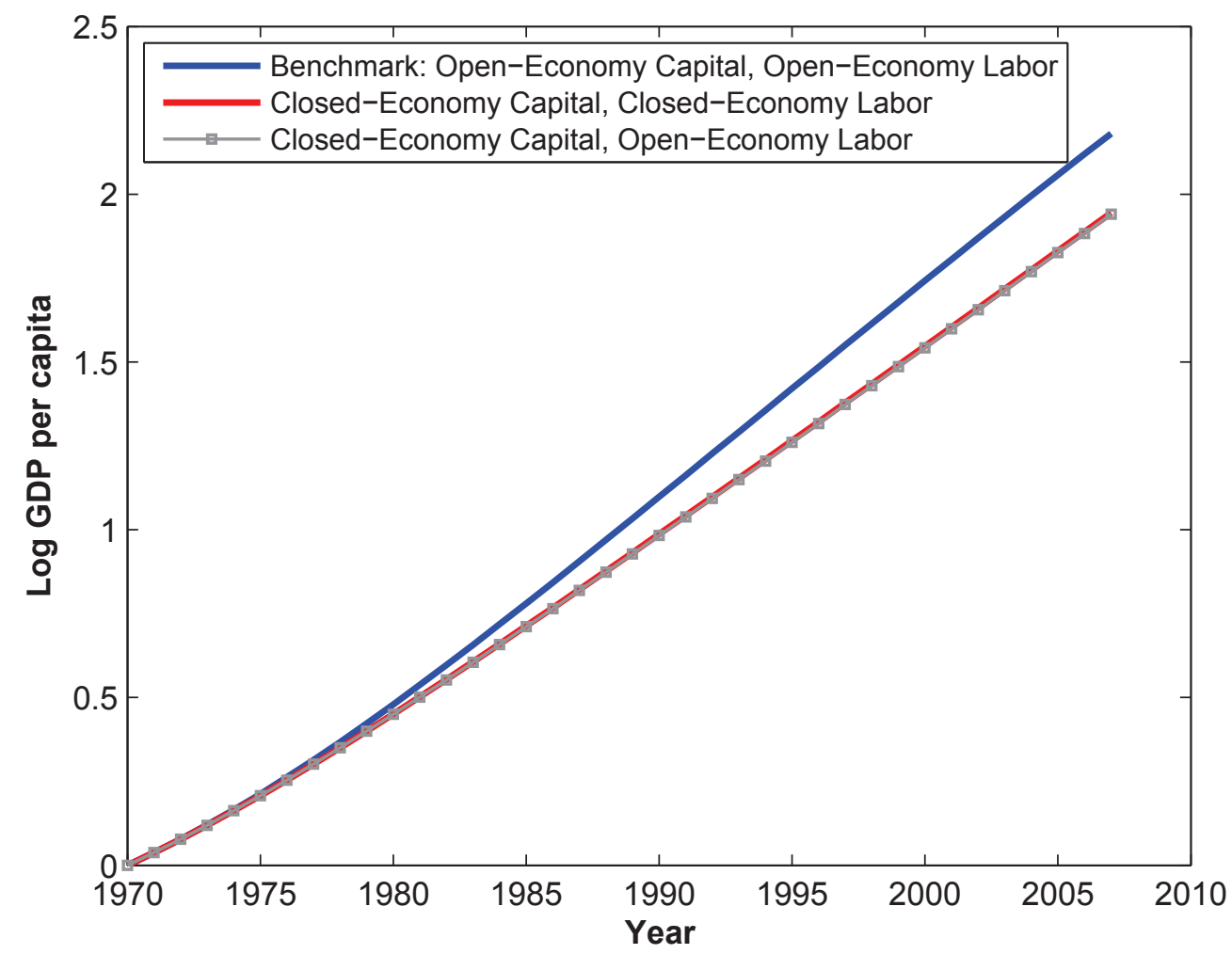


Figure 6: GDP per Capita: Open-Economy Capital and Closed-Economy Labor

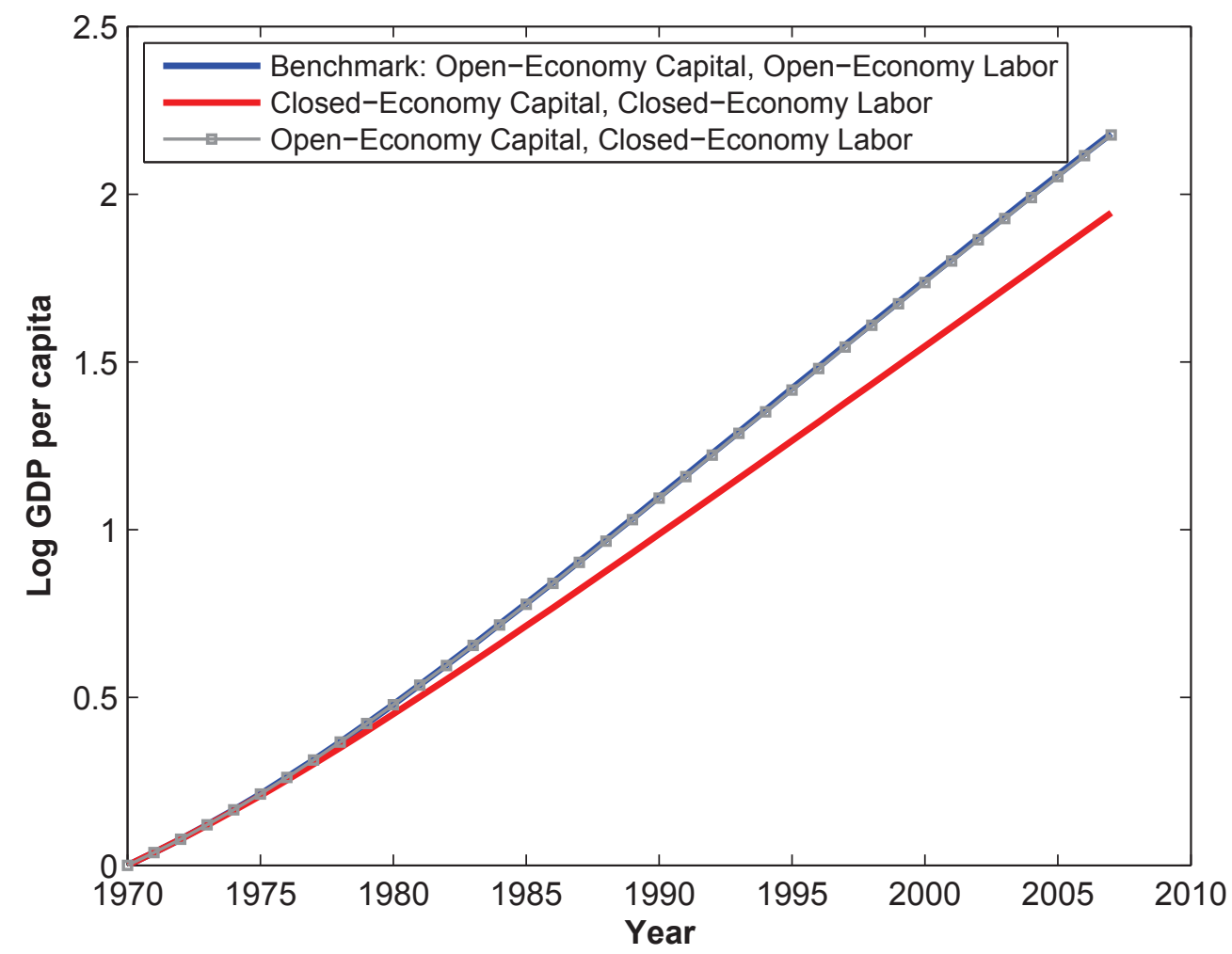

